\title{
Students Awareness of Green Consumer Behaviour and Sustainable Environment in Ghana: Using OpenBugs
}

\author{
Keelson, Solomon Abekah \\ Dept. of Marketing \& Strategy, Takoradi Technical University \\ PO Box 256, Takoradi, Western Region, Ghana \\ Tel: 233-208-150-023Ｅ-mail: unclekeelson@gmail.com
}

\begin{abstract}
Johnson, Joseph Ahinful
Department of Statistics and Actuarial Science, Takoradi Technical University

PO Box 256, Takoradi, Western Region, Ghana
\end{abstract}

Tel: 233-234-431-345_E-mail: josephjohnson83@yahoo.com

Received: June 6, 2020 Accepted: Sep. 7, $2020 \quad$ Published: April 1, 2021

doi:10.5296/jmr.v13i2.18423 URL: https://doi.org/10.5296/jmr.v13i2.18423

\begin{abstract}
Green marketing has been widely studied because of its importance in marketing theory. The purpose of this green marketing study unlike previous ones was to examine student's awareness of how their green consumer behaviour impact environmental sustainability. A total of three hundred and seventeen (317) tertiary students from the Technical Universities of Ghana were used as respondents in a simple random sampling approach, using the internet survey method. Using the OpenBUGS Bayesian statistical technique, the findings of the present study showed an average level of awareness of green products; students consider the potential environmental impact of their actions when making purchase decisions, and as their purchase habits are affected by their concern for the environment. Thus, students are able to distinguish between green product and non-green product. Again, they know the benefits of green products, and would prefer buying green product as first option. Moreover, they believe green buying behavior can contribute to saving the environment because the study showed a direct relationship between buying behavior and the environmental concerns. Finally, the ANOVA results revealed that male students' response to green product is positive compared to their female counterparts, whose response to green product are
\end{abstract}


negative. The study recommended that institutions could include in their marketing curricula subjects that train students on consumer knowledge, awareness, values, attitudes, expectations, perceptions and concerns for the environment.

Keywords: green consumption, green environment, green marketing, green perception, green value 


\section{Introduction}

2021, Vol. 13, No. 2

Consumer attitude, awareness and perception of green product affect the recent increase in behaviour toward the origin of products and the concern over consumption's effect on the environment (Maheshwari, 2014; Mantiaha, 2016; Sharma \& Trivedi, 2016). Consumer green behaviour compels marketers to cultivate green behaviour to gain increasing opportunities to convince consumers to select their products over competitors. Other products' performance variables contribute to the firm's performance but we need an optimum level of greenness to maintain competitive advantage. This green behaviour should therefore lead to environmental sustainability (Cooper, 2005). The concern for green marketing and environmental awareness has gained most attention and raised demanding issues in the academic research. Studies on green consumer behaviour has been vast and varying because of its importance to researchers. Studies have used socio-demographic variables to profile green consumers (Ferrell \& Hartline, 2014; Park, Choi \& Kim, 2012), and found that young adults in the $18-25$ year age group, are most concerned of their natural and social surroundings which impact on their marketplace knowledge and purchase decisions. Similarly, Sharma's (2015) study revealed that socio-demographic characteristics such as age and education level play an important role in influencing the consumer's green awareness and behaviour. Again, Wang (2014) cites previous research studies that have identified among other demographic characteristics, young adults and individuals with high education as the most likely to engage in green consumption behaviour. The literature show that educated young adults are conscious of their immediate environment. It is therefore appropriate to consider such a population in a study that concerns itself with examining green consumer behaviour and green environment. Thus, this study used students of tertiary education in Ghana who falls within the educated young adult population category to evaluate the consumer green awareness and how that contribute environmental sustainability.

A study by Rahman, Barua, Hoque and Zahir (2017) examined consumers' perception towards green values created by the green marketing efforts by the promoters and its impact on their purchasing behaviour of eco-friendly sustainable products. This study also stressed marketers resolve to put in an effort to promote green brand awareness in the consumer's mind relative to the non-green products. Despite the wider scope in the market for green products for consumer groups that have pro-environmental preferences, the paper revealed that green awareness is still low. The findings acknowledged green marketing's ability to ensure a clean and eco-friendly environment. Therefore, as consumers become pro-green, they are in effect pushing for products which production and consumption has little or no effect on the environment, hence creating a clean environment.

Another article by Maheshwari (2014) investigated consumer beliefs and attitude on environment protection and their purchasing behaviour of eco-friendly products. The results showed that to promote and sell products that are environmentally friendly, they need to expose consumers to enough green product marketing communication. The paper suggested that lack of exposure could exploit the market for greener products more within consumer groups that have pro-environmental values. In a related study, a research conducted by 
Govender and Govender (2016) to examine the influence of green marketing on the purchasing behaviour of South African consumers, showed that consumers have enough knowledge on the issues facing the environment. They concluded that elements of the green marketing mix, such as green promotion, often raise awareness and encourage positive change in consumption behaviour. The study showed that although consumers were price sensitive in their purchase decisions, they preferred green products over standard alternatives. We can learn from these studies that consumers' attitudes and beliefs regarding green products is to protect the environment, and the level of green awareness goes a long way to determine the amount of beliefs and attitudes.

In other studies, Sharma and Trivedi (2016) examine how variables such as eco-labels, ecobrands, environmental advertising, environmental awareness, green product, green price, green promotions and demographics, affect the consumer's green marketing behaviour. The result showed that all the green marketing variables affected consumers towards the purchase of green products. According to research globalization, liberalization and privatization, rapid changes in technology, changes in the wants of the humans have seen a magnificent increase in recent years (Boztepe, 2012). This has resulted in the increased pollution levels and depletion of the natural resources. Therefore, the consumer is very particular about his or her environment and would sacrifice any other marketing variables for green product in other to reduce any damage to the environment to minimal levels. Again, Jaju (2016) investigated the impact of Green Marketing on consumer purchasing patterns and decision making in India. The author found that the intensity of green packaging and green branding, importance of green products and premium green pricing have a positive impact on consumer behaviour leading to green purchases. An article by Mantiaha (2016) to examine the influence of green marketing on consumer buying behaviour found that green promotion has a significant positive influence on consumer buying behaviour, but found no significant relationship between green product and consumer buying behaviour. This shows that green product awareness has superior influence on buying behaviour than the absence of green awareness.

Biswas (2016) also contributed to the study of green consumer behaviour when he examined the drivers for green purchase decisions and willingness-to-pay. The results found a relationship between consumers' perception about the functional aspect of green products and their willingness-to-pay. Prior to that, a study by Suki (2013) to examine the influence of consumers' environmental concerns and awareness of green product on their purchasing decision of green products showed that consumers' awareness is significant in purchasing decision of green products. In this direction, a person having concern for the environment and its brand image would have a stronger preference to buy a green product. This would compel companies to adopt green production, which with green consumption behaviour, affect sustainable environment (Sharma \& Trivedi, 2016). Again, a research to access the green values of consumers, their level of awareness about environmental issues, green products and practices, found a high level of awareness and values about green marketing practices and products among the consumers (Bhatia \& Jain, 2013). This result suggested that the consumer green product value and awareness, affect public concern for environmental issues, which influence environmental awareness creation and practices. 
In another development, Sandu (2014) did a study to provide a comprehensive literature review of green marketing, eco-friendly products and green consumers to access how the degree of awareness on different environmental problems affect global concern to reduce negative impact on the environment. The conclusion was that green awareness leads to increased production of organic products, which has increase demand, and this practice helps maintain eco-friendly and sustainable environment. We can deduct from this analysis that green marketing awareness, green values and green production and consumption practices are necessary for having a clean and safe environment. A preceding study by Das, Dash and Padhy (2012) to find how companies handle strategic issues in green marketing, averred that green marketing incorporates a number of activities including, changes to products, changes to the production process and distribution systems, packaging, and changes to marketing communications. The study concluded that green marketing is possible, sustainable and profitable; and marketing strategies is critical for the organization's competitiveness and eco-friendly and sustainable clean environment. Still on the green marketing and environmental concerns, Gbadeyan and Omolekan (2015) examined the challenges and opportunities of green marketing and sustainable development. They concluded that the low awareness level of green marketing among consumers resulted from lack of strategies for effective application of green marketing. They confirmed that lack of sufficient awareness affects green production and green consumption; and this could have an adverse effect on the environment. Lee (2017) conducted a study to examine the impact of the new ecological paradigm, environmental collective efficacy, environmental knowledge, and collectivism on the green purchase intention of Korean and Chinese consumers. The study found that the new ecological paradigm, environmental collective efficacy, environmental knowledge, and collectivism had direct effect on green purchase intention of consumers.

The work of Divyapriyadharshini, Devayani, Agalya, and Gokulapriya (2019) to determine the consumers' awareness about green products and consumers support to the environment if they switch over to green products, revealed that green product awareness is the critical factor which affects consumers green purchasing decision. Therefore, green marketing awareness behaviour promote eco-friendly environment and leads to green cities. The work of Mahat et al. (2019) also supported the significant direct relationship between environmental awareness and consumer green consumption behaviour on developing a sustainable environment, when their study established a relationship between knowledge construct with consumer attitudes, practices, values, and behaviour. In a related article, Ting et al. (2019) explored the relationship between behavioural intentions and green hotel development. The results showed that a positive correlation existed between environmental attitude, subjective norms, perceived behavioural control, positive anticipated emotion, and desire intention. This study, again, confirmed the significant role of green consumer attitude, awareness and perception on green environment.

A cursory evaluation of the empirical studies reveals that green marketing awareness influence consumer green awareness and green perception, which models consumer green behaviour, and consumer green beliefs and attitudes. Thus, green consumer awareness influence companies' green products and production strategies and contribute to promotion 
of eco-friendly environment. While many of the studies (Gbadeyan \& Omolekan, 2015; Lee, 2017; Devayani, Agalya, \& Gokulapriya, 2019; Mahat et al., 2019; Ting et al., 2019) have focused on the relationship between green marketing and consumer buying behaviour and its consequences on environmental sustainability. Yet investigation into consumers value of green products, and their degree of awareness of how their green baying behaviour relates to the environment is under researched. This creates a gap in the instant literature, which needs scientific investigation. In the light of this, the current study focusses on investigating the young educated adults of the Technical Universities in Ghana's value of green product, their green buying behaviour and their awareness of how their consumer green behaviour impact on the physical environment.

\section{Research Questions}

1. What is the level of consumer green awareness among students of Ghana?

2. what is the consumer's green value?

3. How is the students' green buying behaviour?

4. what is the consumer's perception of the relationship between their green buying behaviour and the state of the environment?

\section{Hypotheses}

H1: There is high level of students' awareness of green products in Ghana

$\mathrm{H} 2$ : There is significant consumer green product value among tertiary students in Ghana

H3: Consumers of tertiary institutions would prefer buying green product as first option

H4: Consumers acknowledge that buying behaviour has direct relation with the status of the environment

\section{Literature Review}

\subsection{Green marketing}

Green marketing may refer to production and sale of products that is believed to be environment friendly. It involves activities such as product change, modification of production processes, packaging, labeling, advertising strategies and increased awareness on compliance marketing among industries (American Marketing Association, 1975). This is in line with Dettie, Burchell and Riely (2012) who defined green marketing as the use of marketing mix to facilitate production that satisfy organizational and individual goals and at the same time ensure the preservation, protection and conservation of the natural environment. Focusing on the management responsibility in green marketing practices, green marketing relates to a strategic management practice that identifies, anticipate and satisfies consumer needs in a manner that earns the company profit and also protect and sustains the environment. Tanuj, Sourjo and Arpita (2013) described green marketing practices as a strategic management responsibility, by relating green marketing to a strategic management practice that identifies, expect and satisfies consumer needs in a manner that 
does not only earn profit but also protect and sustains the environment., Bock, Lu and Joseph (2013) described green marketing in relation to a strategic effort made by management of a firm to provide customers with the environment friendly merchandise. This shows that organization's green marketing practice achieves two results - provide customer value and environmental sustainability. Thus, customer attitude, awareness, expectation and perception of green marketing effect on the environment would enable them to put up with green marketing behaviour that would lead to green cities in Ghana.

In a related study, Ansar (2013) defined green marketing as a deliberate marketing effort geared toward production, promotion and consumption practices that safes the environment and can satisfy not only consumers' product needs but also their environmental needs. Thus, although green marketing is like traditional marketing, green marketing involves concern for a safe environment. To support this construct, Diglel and Yazdanifard (2014) described green marketing as a range of activities, which include alteration of the production process, adjustment of product lines and progression in packaging, and transforming advertising to satisfy both consumers' product and environmental needs. Commenting on the activities within green marketing, Datta and Ishaswini, (2011) argued that the green marketing mix "preserves environmental resources and deliver value-added products and services". Another meaning to green marketing by Nandini and Deshpande (2011) is that green marketing involves developing and promoting products and services that satisfy customer wants and needs for quality, performance, affordable price and convenience without having a detrimental impact on the environment. A person concerned about the welfare of the environment and, thus, displays environmentally friendly behaviour, and embraces and purchases eco-friendly products is behaving as a green consumer (Boztepe, 2012). Because of green awareness and green beliefs and attitudes, consumers are becoming mindful about the environment, and socially responsible consumers (Sawant, 2015). Green consumers know that their individual consumption behaviour impact on the environment (Dagher \& Itani, 2014). Therefore, consumers are engaging in environmentally friendly behaviour and are supporting businesses that implement green strategies.

The green marketing practices moves a consumer to buy environmentally sustainable products, with the aim to attaining a balance between the consumption objectives, and society and environmental concern (Samarasinghe, 2012). Firms gain competitive advantage if they use marketing practices that satisfy society's needs and wants, and help to sustain the environment. Green marketing helps a firm improves on its image and create loyal customers, which translate into increased sales and profits (Kotler, 2011). Consumer purchase behaviour has a direct correlation with organization's green marketing practices. Consumers exhibit direct actions that have a positive impact of their immediate environment, in what is called consumerism (Grob, 1995).

\subsection{Green awareness and perception}

Green environmental issues and green awareness in terms of green preference, green management and green branding have generated research interest (Lin \& Huang, 2012). Green awareness refers to the consumers knowledge of and appreciation of how the environment is susceptible to human activities and how the environment can be protected 
through the same human activities and behaviour. Green awareness is the consumers understand that the environment is fragile and need protection from human activities, including green consumption behaviour. Concern for environmental sustainability has compelled many consumers to engage in consumption practices that will encourage companies to increase production to ensure increase production to meet societal needs while protecting the environment for present and future generations (Saha, 2017). With this understanding, green consumer awareness would mean knowledge that enable the consumer to reward green companies and punish non-green companies through buying behaviours. As consumer awareness level increases, he/she comes to terms with how human consumption has created some environmental problems. This level of awareness makes consumers do everything they can to protect the environment and make it green through their purchasing behaviour of buying green products (Pagiaslis \& Krontalis, 2014). As consumers continue to show concern for the environment and preferring products and services that safe the environment (Nimse et al., 2007), such concerns and awareness influence their purchases and consumption behaviour, which in time create eco-friendly attitude called green consumerism (Moisander, 2007). Here, consumers form a perception of green products and services.

We find consumer perception formation towards green products to have a significant, but negative relationship between consumers' corporate perceptions on green products (D'Souza et al., 2006). According to Okada and Mais (2010), the distinction between green firm and non-green firm lies in the extent to which they take proactive measures in environmental sustainability and position themselves based on environmentally sustainable philosophy. D'Souza et al. (2016) found corporate perception, product perception, product label and experience, as determining consumers' perception formation towards a green product. Research confirm that consumer's perception of an organization's corporate strategies towards environmental issues contributes to formation of the overall perception about green products. The findings showed that the Consumers would have a general perception on corporate policies that did not support firms that placed higher profitability in implementing green product strategies (Kong et al., 2014). Therefore, consumers who considered environmental issues when making a purchase are more likely to prefer green product to non-green products (Barber, 2010). This creates consumers' perception formation as they develop long lasting attitudes, behaviours, values, and intention toward green products.

\subsection{Green buying behaviour and green environment}

Consumer green purchasing behaviour starts with the consumer's awareness and understanding common green marketing practices expected from the producer include recycling, purchasing organic food, using less paper, saving electricity, avoiding aerosols and plastic bags (Gilg, Barr \& Ford, 2005). As consumers become more concern of green marketing, they come to realize the effect of their own behaviour on the environment. Thus, they make buying a green product a priority over any other considerations, including price. Research has supported how consumers are focusing on the product of green companies, relative to non-green ones (Han et al., 2010). Previous studies have identified consumer 
knowledge, awareness, values, attitudes, expectations, perceptions and concerns for the environment as factors that influence consumers' pro-environmental behaviour (Oliver, Volschenk \& Smit, 2011). In this way, consumers who are conscious of green marketing and its relationship with green environment might even sacrifice perceived quality products and services for lower quality products and services that provide a safe and clean environment (Han et al., 2010). Therefore, we believe that students' awareness, concern and perception of green consumption would influence their ultimate purchasing behaviour toward green product and lead to green cities in Ghana.

Studies confirm that when consumers are concern about the environment, they turn to prefer purchase of green product to non-green product (Grant, 2007). Though other studies failed to support that when consumers are concerned about the environment, they will purchase green products (Mc Eachern, Warnaby, Carrigan \& Szmigin, 2010, cited in Solomon, Bamossy, Askegaard \& Hogg, 2010), the positive effect of buying behaviour on the environment cannot be overemphasize (Saha, 2017; Samarasinghe, 2012)

Consumer green awareness and buying behaviour is seen to have a correlation with the concern for the natural environment and its momentous ecosystem (Kaufmann, Pianni \& Orphanidou, 2012). Thus, a conscious consumer makes buying decisions that A sustainable consciousness describes making more decision regarding the promote and preserve the natural environment as well as sustaining green society for the future (Carrete, Castaño, Felix, Centeno \& González, 2012). In this way, the consumer recognizes the effect of his/her behaviour on the environment and feel responsible to prevent any negative effect of his/her buying behaviour on the environment. Kang, Lui and Kim (2013) learned that a consumer who is conscious and concern for green environment is more likely to exhibit perception towards sustaining the environment, and incline toward purchase eco-friendly products. Studies acknowledge that consumers are aware that their consumption behaviour impacts on the environment and that place a social responsibility on them to help safe the environment through their buying behaviour (Sawant, 2015; Dagher \& Itani, 2014). As a result, consumers engage in environmentally-friendly behaviour and support firms that implement green strategies to support the environment (Ansar, 2013).

\section{Material And Methods}

This study uses OpenBUGS (Windows for Bayesian Inference Using Gibbs Sampling) which is a programming language-based software use to generate random sample from the posterior distribution of parameters of a Bayesian model. In the current study, we first evaluate and rank the responses from each categorical variable measuring green product. Afterward, we use two - way analysis of variance (ANOVA) to establish the posterior relationship between each of these categorical variable and gender.

\subsection{Evaluation and ranking of responses}

In using categorical variables there is a need to evaluate and rank responses of each factors constituting the variable under consideration. This set as a preliminary analysis leading to further analysis. In the current study the responses of each categorical variable were evaluated and ranked to ascertain which response is performing well within each category 
of variable. There is a facility in OpenBUGS that monitor some ranked - related statistics on the basis of some specific stochastics vector nodes which can estimate or predict performances.

\subsection{Two - Way ANOVA in OpenBUGS}

In considering consumer attitude, awareness and perception of a product, we assume these variables as categorical explanatory variables with continuous response variable $Z$. Let assume two categorical Variables $A$ and $B$ with $L_{A}$ and $L_{B}$ levels respectively. If we assume a normal distribution for the response $Z$ and the data is in the tabular form of a given size $L_{A} \times L_{B}$ with $n_{a b}$ observed in each cell, then the model is given as

$$
Z_{a b k} \sim N\left(\mu_{a b}^{\prime}, \sigma^{2}\right) \text { where } \mu_{a b}^{\prime}=\mu_{0}+\alpha_{a}+\beta_{b}+\alpha \beta_{a b}
$$

for $k=1,2, \ldots ., n_{a b}$ where $a=1,2, \ldots, L_{A} ; b=1,2, \ldots, L_{B} ; \mu_{0}$ is the overall common mean parameter which is also a constant ; $\alpha_{a}$ and $\beta_{b}$ are parameters for categorical variable $A$ and $B$ respectively and $\alpha \beta_{a b}$ interaction term.

In this model the objective is to determine the mechanism leading to the outcome of response variable, $Z$ since this is a random variable, uncertain. Again, two factors are used in this model leading to two - away analysis of variance (ANOVA) because in considering consumer attitude, awareness, perception others, it is also believed that at least there might be one factor such as age, gender, education which influences such a decision.

In OpenBUGS which is a software for Bayesian analysis, which allow generalization of the analysis of variance (ANOVA) involving categorical analysis, a constraint is often imposed on the parameters. The constraint gives interpretation and practical meaning of the parameters. The most known constraints are:

Corner Constraints in this constraint, the effect of a level $\boldsymbol{r}=\left\{\mathbf{1}, \mathbf{2}, \ldots, \boldsymbol{L}_{\boldsymbol{A}}\right.$ is set equal to zero: $\alpha_{r}=0$. Where $r$ is referred to as the baseline or reference category for factor $A$.

Sum -to - Zero Constraints (STZ) in the likelihood one parameter is substituted with the function resulting to the following constraint

$$
\sum_{a=1}^{L_{A}} \alpha_{a}=0
$$

This constraint term captures an overall mean effect.

The prior for $\mu_{0}$ and $\alpha_{a}, \beta_{b}, \alpha \beta_{a b}$ is considered using a simple normal distribution with mean zero and the variance is substituted with parameter $\tau$ which is precision and gamma is the corresponding prior for this precision, $\tau \sim \operatorname{gamma}(a, b)$. However, because there is no information available we used low prior to express our prior ignorance. The use of precision is to make it compatible with OpenBUGS system. If the data is specified as 
$L_{A} \times L_{B}$ column the likelihood can be specified using triple loop in OpenBUGS in order to define all elements of the response array $z$. In view of this we can specify the model in terms of precision by

$z_{a b k} \sim N\left(\mu_{a b}^{\prime}, \tau^{-1}\right)$
for $k=1,2, \ldots ., n_{a b}$ where $a=1,2, \ldots, L_{A}$ and $b=1,2, \ldots, L_{B}$.

\subsection{Data collection method}

This study used the quantitative survey method. We distributed the questionnaire online via the social media platforms, including Watts up, Email, Moodle, the Facebook. We chose the online platform because it is less intrusive and it allows a wider coverage on respondents. It is also because of the Covid-19, students were not on campuses to make face-to-face data collection possible (May and June 2020). Many of the respondents were not marketing students and might not understand the technical terms such as green marketing, green consumption and green environment. A brief explanation of these concepts was sent together with the questionnaire to help the respondent understand what is expected so they can answer objectively. We selected 350 consumers from all the ten Technical Universities in Ghana. We used the simple random sampling technique and sent the questionnaire to the social media platforms of students for anybody who wishes to take part in the survey did so. Participation of respondents was voluntary.

\section{Results and Discussion}

The data for this study constitute three hundred and seventeen (317) respondents across ten (10) Tertiary students in Ghana. In OpenBUGS the responses were coded with three thousand (3000) iteration, after discarding initial thousand (1000) iteration as burn in period, we sampled from two thousand (2000) and the result is shown below. The first part is the evaluation and ranking of the responses for each categorical variable which is the preliminary analysis and the second part of the analysis is posterior summaries of two -way ANOVA model for each categorical variable and gender. In using gender, we were assessing the influence of this variable on green product.

\subsection{Evaluations and ranking of categorical responses of green product}

The tables below show the posterior evaluation and ranking of green product awareness, green consumer value, purchasing behaviour for green products and relationship between purchasing behaviour and environment. In measuring these variables there were five (5) factors each measuring these variables. The green product awareness responses were categorized using very low (1), low (2), average (3), high (4) and very high (5). However, green consumer value, purchasing behaviour for green products and relationship between purchasing behaviour and environment were measured using Likert scale, strongly disagree (1), disagree (2), undecided (3), agree (4) and strongly agree (5). The result is shown below. 
Table1. Posterior ranking of green product awareness

$\begin{array}{lcll}\text { Node } & \mathbf{2 . 5 \%} & \text { Median } & \mathbf{9 7 . 5 \%} \\ \text { Awareness [1\} } & 1 & 1 & 3 \\ \text { Awareness [2] } & 1 & 2 & 3 \\ \text { Awareness [3] } & 4 & 5 & 5 \\ \text { Awareness [4] } & 4 & 4 & 5 \\ \text { Awareness [5] } & 1 & 3 & 3\end{array}$

Table 2. Posterior ranking of green consumer value

$\begin{array}{llll}\text { Node } & \mathbf{2 . 5 \%} & \text { Median } & \mathbf{9 7 . 5 \%} \\ \text { Value [1] } & 1 & 1 & 2 \\ \text { Value [2] } & 1 & 2 & 2 \\ \text { Value [3] } & 3 & 3 & 3 \\ \text { Value [4] } & 5 & 5 & 5 \\ \text { Value [5] } & 4 & 4 & 4\end{array}$

Table 3. Posterior ranking of purchasing behaviour for green product

$\begin{array}{llll}\text { Node } & \mathbf{2 . 5 \%} & \text { Median } & \mathbf{9 7 . 5 \%} \\ \text { Behaviour [1] } & 1 & 1 & 2 \\ \text { Behaviour [2] } & 1 & 2 & 2 \\ \text { Behaviour [3] } & 3 & 3 & 3 \\ \text { Behaviour [4] } & 5 & 5 & 5 \\ \text { Behaviour [5] } & 4 & 4 & 4\end{array}$

Table 4. Posterior ranking of relationship between purchasing behaviour and environment

$\begin{array}{lccc}\text { Node } & \mathbf{2 . 5 \%} & \text { Median } & \mathbf{9 7 . 5 \%} \\ \text { PurEn [1] } & 1 & 1 & 2 \\ \text { PurEn [2] } & 1 & 2 & 2 \\ \text { PurEn [3] } & 3 & 3 & 3 \\ \text { PurEn [4] } & 5 & 5 & 5 \\ \text { PurEn [5 } & 4 & 4 & 4\end{array}$

In table1 the median of the rank for each level of awareness is given within the $2.5-97.5 \%$ percentiles. We can observe that category three (3) which is "average" knowledge in green awareness dominates the response on green awareness with median of five (5), lower boundary (2.5\%) of 4 and upper boundary $(97.5 \%)$ of 5 . The second category is those with" high" level of green product awareness. This indicate that the awareness level of green 
product within the population under study is significant. Table 2 shows that category four (4, "agree") dominates green consumer value and this is followed by category five (5, strongly agree). Therefore, it clear that majority of respondents pay attention to consumer value of green product. Again, Table 3 indicate that category four (4, agree) and category five (5, strongly agree) supersede when considering responses on purchasing behaviour of green product. This is the same for Table 4 which gives the categorical responses of relationship between purchasing behaviour and environmental concerns. The values on Table 4 shows that category four (4, agree) and five (strongly agree) dominates all other category of responses. We are $95 \%$ sure of the above responses.

These findings answer the four-research question in this study. In the first instance, it is clear that the level of awareness of green products among students of the Technical Universities in Ghana is on average level. The above findings further show that the awareness is on higher ascendancy as the next highest response indicates on the table1. This means among other things; most (above average number) students are able to distinguish between green product and non - green product and again they know the benefit of green products.

The findings above also reveal that there is significant consumer green product value among tertiary students in Ghana. This implies many of the students consider the potential environmental impact of their actions when making purchase decisions and also as their purchase habits are affected by their concern for the environment

Again, it is obvious consumers of tertiary institutions would prefer buying green product as first option most of them agree to their purchasing behaviour to green product. In this vain, among other things they consider while buying is reading the label of the product to see if the contents are environmentally safe before buying, they avoid buying products from companies which are not environmentally responsible and they buy products with enough information to confirm their greenness.

Finally, there is enough evidence from above findings that consumers of this study acknowledge the direct relationship between buying behaviour and their environmental status. In other words, they agree that littering of the environment is a serious issue and green buying behaviour can contribute to saving the situation. Moreover, they agree to pay extra price for a green product because consumers of this study are aware of how such environment friendly products can save their environment.

\subsection{Posterior summaries of two - way analysis of variance (ANOVA)}

In each of the tables below is the posterior summaries for the MCMC algorithm for 3000 iterations while the initial 1000 was discarded after the burn in period. The tables contain posterior summaries for each of the four categorical variables: green product awareness, green consumer value, purchasing behaviour of green product and relationship between purchasing behaviour and environment against gender. 
Table 5. Posterior summaries of parameters of interaction in two- way ANOVA for green awareness and gender

\begin{tabular}{|c|c|c|c|c|c|c|c|c|}
\hline Node & Mean & Sd & MC-Error & $2.5 \%$ & Median & $97.5 \%$ & Start & Sample \\
\hline Awareness [2] & 4.749 & 5.604 & 0.4679 & -6.13 & 4.677 & 16.59 & 1001 & 2000 \\
\hline Awareness [3] & 44.14 & 5.636 & 0.4412 & 32.89 & 44.1 & 54.83 & 1001 & 2000 \\
\hline Awareness [4] & 36.15 & 5.616 & 0.4518 & 25.77 & 36.11 & 47.41 & 1001 & 2000 \\
\hline Awareness [5] & 9.169 & 5.582 & 0.4068 & -1.756 & 9.133 & 20.41 & 1001 & 2000 \\
\hline Gender [2] & -0.1611 & 5.381 & 0.4945 & -11.47 & -0.0609 & 9.701 & 1001 & 2000 \\
\hline Awereness.gender [2,2] & 1.172 & 7.824 & 0.633 & -14.28 & 1.1321 & 7.21 & 1001 & 2000 \\
\hline Awereness.gender[3,2] & -12.43 & 7.541 & 0.5741 & -26.28 & -12.48 & 2.749 & 1001 & 2000 \\
\hline Awereness.gender[4,2] & -11.8 & 7.817 & 0.601 & -26.94 & -11.94 & 3.849 & 1001 & 2000 \\
\hline Awereness.gender[5,2] & -7.516 & 7.589 & 0.5296 & -21.74 & -7.74 & 8.279 & 1001 & 2000 \\
\hline mu0 & 16.02 & 3.938 & 0.3724 & 7.912 & 16.27 & 23.25 & 1001 & 2000 \\
\hline $\mathrm{s}$ & 8.872 & 0.9902 & 0.02726 & 7.196 & 8.783 & 11.09 & 1001 & 2000 \\
\hline
\end{tabular}

Table 6. Posterior summaries of parameters of interaction in two- way ANOVA for green value and gender

$\begin{array}{lcccccccr}\text { Node } & \text { Mean } & \text { Sd } & \text { MC-Error } & \mathbf{2 . 5 \%} & \text { Median } & \mathbf{9 7 . 5 \%} & \text { Start } & \text { Sample } \\ \text { Value [2] } & 1.843 & 5.986 & 0.461 & -10.15 & 1.993 & 13.17 & 1001 & 2000 \\ \text { Value [3] } & 27.18 & 6.142 & 0.4774 & 14.36 & 27.12 & 39.0 & 1001 & 2000 \\ \text { Value [4] } & 69.23 & 5.952 & 0.4338 & 57.18 & 69.08 & 81.1 & 1001 & 2000 \\ \text { Value [5] } & 45.13 & 5.865 & 0.4502 & 33.75 & 45.31 & 56.26 & 1001 & 2000 \\ \text { Gender [2] } & -2.417 & 6.007 & 0.5794 & -13.65 & -2.541 & 10.02 & 1001 & 2000 \\ \text { Value.gender [2,2] } & 2.146 & 8.82 & 0.6878 & -15.6 & 2.351 & 19.89 & 1001 & 2000 \\ \text { Value.gender[3,2] } & -4.066 & 8.73 & 0.6905 & -22.23 & -3.837 & 13.03 & 1001 & 2000 \\ \text { Value.gender[4,2] } & -18.22 & 8.642 & 0.6601 & -35.74 & -17.88 & -1.054 & 1001 & 2000 \\ \text { Value.gender[5,2] } & 0.3877 & 8.441 & 0.6778 & -16.08 & 0.556 & 16.24 & 1001 & 2000 \\ \text { mu0 } & 6.206 & 4.191 & 0.399 & -1.872 & 6.056 & 14.73 & 1001 & 2000 \\ \text { s } & 9.684 & 1.074 & 0.02791 & 7.829 & 9.597 & 12.0 & 1001 & 2000\end{array}$


Table 7. Posterior summaries of parameters of interaction in two- way ANOVA for purchasing behaviour and gender

$\begin{array}{lllllllll}\text { Node } & \text { Mean } & \text { Sd } & \text { MC-Error } & \mathbf{2 . 5 \%} & \text { Median } & \mathbf{9 7 . 5 \%} & \text { Start } & \text { Sample } \\ \text { Behaviour [2] } & 2.869 & 4.362 & 0.3653 & -5.598 & 2.813 & 12.1 & 1001 & 2000 \\ \text { Behaviour [3] } & 19.07 & 4.385 & 0.3444 & 10.31 & 19.03 & 27.39 & 1001 & 2000 \\ \text { Behaviour [4] } & 66.2 & 4.371 & 0.3527 & 58.11 & 66.17 & 74.96 & 1001 & 2000 \\ \text { Behaviour 5] } & 55.36 & 4.344 & 0.3176 & 46.84 & 55.32 & 64.13 & 1001 & 2000 \\ \text { Behaviour.gender [2,2] } & -2.936 & 6.093 & 0.495 & -14.89 & -2.969 & 9.535 & 1001 & 2000 \\ \text { Behaviour.gender[3,2] } & -2.365 & 5.871 & 0.449 & -13.18 & -2.404 & 9.452 & 1001 & 2000 \\ \text { Behaviour.gender[4,2] } & -16.06 & 6.087 & 0.4698 & -27.86 & -16.16 & -3.907 & 1001 & 2000 \\ \text { Behaviour.gender[5,2] } & -7.483 & 5.909 & 0.4144 & -18.55 & -7.675 & 4.806 & 1001 & 2000 \\ \text { Gender [2] } & -0.4945 & 4.193 & 0.3867 & -9.311 & -0.4207 & 7.196 & 1001 & 2000 \\ \text { mu0 } & 6.153 & 3.066 & 0.2907 & -0.1189 & 6.342 & 11.77 & 1001 & 2000 \\ \text { s } & 6.887 & 0.769 & 0.02118 & 5.584 & 6.818 & 8.615 & 1001 & 2000\end{array}$

Table 8. Posterior summaries of parameters of interaction in two- way ANOVA for relationship between purchasing behaviour and gender

$\begin{array}{lclllllll}\text { Node } & \text { Mean } & \text { Sd } & \text { MC-Error } & \mathbf{2 . 5 \%} & \text { Median } & \mathbf{9 7 . 5 \%} & \text { Start } & \text { Sample } \\ \text { PurEn [2] } & 146 & 6.243 & 0.5203 & -8.993 & 3.071 & 16.35 & 1001 & 2000 \\ \text { PurEn [3] } & 26.79 & 6.28 & 0.4905 & 14.25 & 26.76 & 38.69 & 1001 & 2000 \\ \text { PurEn [4] } & 71.06 & 6.259 & 0.5026 & 59.5 & 71.01 & 83.6 & 1001 & 2000 \\ \text { PurEn [5] } & 46.34 & 6.221 & 0.4523 & 34.16 & 46.3 & 58.85 & 1001 & 2000 \\ \text { PurEn. Gender [2,2] } & 2.553 & 8.714 & 0.7033 & -14.69 & 2.504 & 20.4 & 1001 & 2000 \\ \text { PurEn.Gender [3,2] } & -2.131 & 8.4 & 0.6377 & -17.52 & -2.18 & 14.79 & 1001 & 2000 \\ \text { PurEn.Gender [4,2] } & -22.71 & 8.71 & 0.6681 & -39.62 & -22.87 & -5.259 & 1001 & 2000 \\ \text { PurEn.Gender[5,2] } & -1.529 & 8.455 & 0.5883 & -17.39 & -1.782 & 16.08 & 1001 & 2000 \\ \text { Gender [2] } & -1.525 & 5.992 & 0.5495 & -14.12 & -1.421 & 9.454 & 1001 & 2000 \\ \text { mu0 } & 5.405 & 4.386 & 0.4141 & -3.644 & 5.678 & 13.47 & 1001 & 2000 \\ \text { s } & 9.902 & 1.105 & 0.03047 & 8.032 & 9.799 & 12.4 & 1001 & 2000\end{array}$

In the first instance, Tables5 to Table 8 give us indication that the posterior modeling using ANOVA in each Table was successfully converged as the value Sd (Standard deviation) is larger than the values of MC-Error (Markov Chain Error). Again, in all the four tables (Table5 to Table8), indicate that the mean value for each parameter including the interaction terms are far from zero which show that both gender (Male and female) and each categorical variable influences the responses on green product. However, it is evident that as categorical response of male is positively associated with green product, it is negatively associated with the female response. This is shown as we observe the mean score of each categorical response for male being posteriori positive while almost all (except the parameter node [2, 2] which is the interaction between categorical response two [2] and female [2] in the case of green awareness, consumer green value and relationship between purchasing behaviour and environment that is positive ) the female interaction terms for each categorical response being posteriori negative. 
Again, on Table5 we observed that the highest positive effect of green awareness on male students is categorical response awareness [3] with posteriori expected value of 44.14. This finding supports the ranking of categorical response above. Meaning, the awareness level of green product for the students in this study is average followed by high [4] with posterior expected value of 36.15 and the posterior distribution of the standard deviation is expected to be equal to 8.872 . Table 6 shows that the highest positive effect of consumer green value on male students is categorical response value [4] with posteriori expected value of 69.23 and its posterior distribution for the standard deviation is expected to be equal to 9.684. This implies most male students agree that they value green product and this can be said of their purchasing behaviour and relationship they perceive between purchasing behaviour and their environment on Table7 and Table 8 as they agree with posterior expected values of 66.2(Standard deviation, 6.887) and 71.06 (standard deviation 9.902) respectively.

The ANOVA findings above gives an indication of interaction between gender and green product. The findings show that indeed gender contribute to green product among tertiary students. However, male students' response to green product is positive compare to their female whose response to green product are negative.

\section{Conclusions}

Based on extensive literature review and the analysis and discussion of findings, the current article provides a set of explanatory variables of green consumption behaviour. It is regarded as the basis for a consensus for understanding the green awareness and value, as well as the consumption behaviour and how they relate to environmental concerns, as a means of persuading consumers to have positive attitude and perception toward green product, and to buy green products which in turn will help to improve the quality of the immediate environment. As a result, this information is a crucial source for informing marketing strategies and approaches of green product-oriented companies and green-conscious consumers. By understanding appreciation of the relationship between consumption behaviour and green environmental concerns, companies can produce and persuade their customers to buy green products which in turn will help to improve the quality of environment. Also, consumerists could persuade society to be green environmentally conscious through their purchases behaviour by using the students as a first point of call. As a quantitative study, the article reviewed relevant literature on green marketing, green perception and green consumer value and how they influence consumer to purchase green product, with green environment in mind as the end product, as a means of answering the research questions. Hypotheses were proposed and OpenBUGS conducted for evaluation and ranking of categorical responses of green product awareness, green consumer value, green purchase behaviour and the relationship between green purchase behaviour and the environment. Then we used ANOVA to examine the parameters of interaction for the green constructs and gender.

Results show that the level of awareness of green products amongst tertiary students in Ghana is average. Also, the students consider the potential environmental impact of their actions when making purchase decisions, and as their purchase habits are affected by their concern for the environment; and that among other things, most students are able to 
distinguish between green product and non - green product. Again, they know the benefits of green products. Consumers of tertiary institutions would prefer buying green product as first option. Moreover, green buying behaviour can contribute to saving the environment as tertiary students acknowledge the direct relationship between buying behaviour and the environmental status. Finally, male students' response to green product is positive compared to their female counterparts, whose response to green product are negative.

The findings of this study extends the research of green consumption in four important ways .First, the current paper extends existing research on the relationship between consumer green buying behaviour and the conscious care for the environment from the tertiary students' perspective, which also contributes to body of knowledge of research that explores the relationship above in a Ghanaian context. On the one hand, there is a growing literature focusing on the relationship between environmental responsibility and green consumption behaviour, but most of which merely focuses on the determinants from the perceptive of producers and suppliers, and less on the consumers responsibility to the environment (Chuang \& Huang, 2018; Su, Swanson, Hsu \& Chen, 2017). Second, this study introduces an important variable to explain the positive effect of consumers' green environmental consciousness on green consumption behaviour, which reveals that consumer's environmental concerns is a critical antecedent for green consumption behaviour. The finding is in line with (Devayani, Agalya, \& Gokulapriya, 2019; Malik, Singhal \& Tiwari, 2017) whose study reveal that environmental concerns play a mediating role in green consumption.

Third, this study contributes to previous studies by investigating the interaction between gender and green product variables. Specifically, this study provides empirical evidence that indeed gender contribute to green product among tertiary students. However, male students' response to green product is positive compare to their female whose response to green product are negative. The result is consistent with previous research the concluded that socio-demographic characteristics such as gender and education level play an important role in influencing the consumer's green awareness and behaviour (Sharma, 2015). Fourth, the current study contributes to the extant literature on the level of green environmental responsibility of young adult in society. The result found a relatively high level of green awareness and green product value as well as direct positive relationship between green purchase behaviour and the environment among tertiary students. This finding is consistent with the study of Choi \& Kim (2012), which revealed that young adults in the 18 to 25 year age group, are most concern of their natural and social surroundings which impact on their marketplace knowledge and purchase decisions. It is also in line with the work of Wang (2014) cites previous research studies that have identified among other demographic characteristics, young adults and individuals with high education as the most likely to engage in green consumption behaviour.

\section{Managerial Implications and Scope for Further Research}

On the bases of the findings and conclusions the following implications are outlined:

Academic Implication: The tertiary institutions could include in their curricula subjects that 
train students on consumer knowledge, awareness, values, attitudes, expectations, perceptions and concerns for the environment as factors that influence consumers' proenvironmental behaviour (Oliver, Volschenk \& Smit, 2011). This is because when consumers are concern about the environment, they turn to prefer purchase of green product to non-green product (Grant, 2007)

Practical implication: This study can help companies, and sellers who want to be competitive by attracting among others the majority of green consumers to buy their product, and together participate in solving environmental issues. Producers can use these green motivators to persuade consumers for choosing green products, and to adopt societal marketing orientation. By so doing, the producers gain market share and possibly profitability, and the environment is also sustained

Social implication: The current study will contribute to public understanding, knowledge, and attitude for going green and do their part to commit in solving environmental issues and make less negative impact on the environmental. It is significant that as consumers are motivated to buy green products, this will contribute to both clean environment and healthy life.

Policy implication: The environmental protection Council and the Ministry of Environment Science and Technology can promote improved quality environment for clean Ghana by starting the campaign with the tertiary institution and narrow it down to the other education institutions. These can carry the crusade across the country and can influence friends, relatives and neighbors to support developing green environment through green consumer behaviour.

Future Research: The scope of the study is tertiary students, therefore making the results begs from generalization. A cross sectional and cross-country study could be more useful for generalization. Future studies can consider widen the scope to enhance generalization. The relationship between consumption behaviour and green environment may also be influenced by geographical factors and personal attitudes, apart from gender. These dimensions can also be used by future authors to study whether how people in different geographical areas and with different attitude are influenced by which extent and could influence their purchasing decision in an environmentally friendly way.

\section{Acknowledgement}

We are grateful to Solomon A. Keelson for careful research design, data collection and preparation and review of the manuscript. We also acknowledge Johnson J. K. Arhinful for performing the statistical analysis and interpretation of data. We gracefully acknowledge all authours whose works contributed greatly to the current study.

\section{References}

American marketing Association (1975) 
Ansar, N., (2013). Impact of Green Marketing on Consumer Purchase Intention. Mediterranean Journal of Social Sciences, 4(11), 650-655. https://doi.org/10.5901/mjss.2013.v4n11p650

Barber, N (2010). Greenwine packaging: Targeting environmental consumers. International Journal of Wine Business Research, 22(4), 423-444. https://doi.org/10.1108/17511061011092447

Bhatia, M. \& Jain, A. (2013). Green Marketing: A study of Consumer Perception and Preferences in India. Electronic Green Journal, 1(36), 1-19. https://doi.org/10.5070/G313618392

Biswas, A. (2016). A Study of Consumers' Willingness to Pay for Green Products. Journal of Advanced Management Science, 4(3), 211-215. https://doi.org/10.12720/joams.4.3.211215

Bock, Lu, L \& Joseph M. (2013). Green marketing: what the Millennials buy. Journal of Business Strategy, 34(6). https://doi.org/10.1108/JBS-05-2013-0036

Boztepe, A. (2012). Green Marketing and its Impact on Consumer Buying Behaviour. European Journal of Economics and Political Studies, 5(1), 5-21.

Carrete, L., Castaño, R., Felix, R., Centeno, E., and González, E. (2012). Green consumer behaviour in an emerging economy: confusion, credibility, and compatibility. Journal of Consumer Marketing, 29(7), 470-481. https://doi.org/10.1108/07363761211274983

Chuang, S.P.; Huang, S.J. The effect of environmental corporate social responsibility on environmental performance and business competitiveness: The mediation of green information technology capital. J. Bus. Ethics 2018, 150, 991-1009. https://doi.org/10.1007/s10551-016-3167-x

Cooper, T. (2005). Slower consumption reflections on product life spans and the "throwaway society. Journal of Industrial Ecology, 9(1-2), 51-67. https://doi.org/10.1162/1088198054084671

D’ Souza, C., Taghian, M., Lamb, P. \& Peretiatkos, R. (2006). Green Products and Corporate Strategy: An Empirical Investigation. Society and Business Review, 1(2), 144-157. https://doi.org/10.1108/17465680610669825

Dagher, G.K \& Itani, O. (2014) Factors influencing green purchasing behaviour: Empirical evidence from the Lebanese consumers. Journal of Consumer Behaviour, 13, 188-195. https://doi.org/10.1002/cb.1482

Das, SM, Dash, BM \& Padhy, PC (2012) Green Marketing Strategies for Sustainable Business Growth, Journal of Business Management \& Social Sciences Research, 1(1), 8287.

Datta, S.K. \& Ishawini (2011). Pro-Environmental concern influencing Green Buying: A Study on Indian Consumers. International Journal of Business and Management, 6(6), 124133. https://doi.org/10.5539/ijbm.v6n6p124

Diglel, A. \& Yazdanifard, R. (2014). Green Marketing and its Influence on Buying 
Behaviour and the Attitudes of Purchasers towards Eco-friendly Products. Global Journal of Management and Business Research, 7(11), 11-18.

Ferrell, O.C. and Hartline, M.D. (2014). Marketing Strategy: Text and Cases. 6th ed. South Western Cengage Learning.

Gbadeyan, R. A. \& Omolekan, O. J. (2015). Relevance of green marketing on environmental degradation: an empirical study of consumers of green products in Benin- City, Nigeria, University of Mauritius Research Journal, 21, 1-10.

Gilg, A., Barr, S., \& Ford, N. (2005). Green consumption or sustainable lifestyles? Identifying the sustainable consumer. Futures, 37(6), 481-504. https://doi.org/10.1016/j.futures.2004.10.016

Govender, J.P \& Govender T.L. (2016). The Influence of Green Marketing on Consumer Purchase Behaviour. Environmental Economics, https://doi.org/10.21511/ee.07(2).2016.8

Grant, J. (2007). The Green Marketing Manifesto. London: John Wiley and Son Ltd

Grob, A. (1995). A structural model of environmental attitudes and behaviour. Journal of Environmental Psychology, 15(3), 209-220. https://doi.org/10.1016/0272-4944(95)90004-7

Han, H., Hsu, L. \& Sheu, C. (2010). Application of the Theory of Planned Behaviour to green hotel choice: Testing the effect of environmentally friendly activities. Tourism Management, 31, 325-334. https://doi.org/10.1016/j.tourman.2009.03.013

Jaju A. (2016). A study of the Impact of Green Marketing on Consumer Purchasing Patterns and Decision Making in Telangana, India. Masters thesis, Dublin, National College of Ireland

Kang, J. Liu, C \& Kim, JH (2013) Environmentally sustainable textile and apparel consumption: the role of consumer knowledge, perceived consumer effectiveness and perceived personal relevance International Journal of Consumer Studies, 37(4), 442-452. https://doi.org/10.1111/ijcs.12013

Kong, W, Harun, A. Sulong, R \& Laratin, L (2014) The Influence of Consumers Perception of Green Products on Green Purchase Intention, International Journal of Asian Social Science, 4(8), 924-939

Kotler P. (2011). Reinventing marketing to manage the environmental imperative. Journal of Marketing, 75(4), 132-135. https://doi.org/10.1509/jmkg.75.4.132

Lee, Y.K. (2017). A Comparative Study of Green Purchase Intention between Korean and Chinese Consumers: The Moderating Role of Collectivism. Sustainability, 9(10), 1-17. https://doi.org/10.3390/su9101930

Lin, P. \& Huang, Y. (2012). The Influence Factors on Choice Behaviour Regarding Green Products Based on the Theory of Consumption Values, J. Clean. Prod. 22, 11-18. https://doi.org/10.1016/j.jclepro.2011.10.002 
Mahat, H Hashim, M. Saleh, Y. Nayan, N \& Norkhaidi, SB. (2019). Environmental Sustainability Knowledge, Attitude and Practices among Pre-school Students, IOP Conf. Series: Earth and Environmental Science 286. https://doi.org/10.1088/1755$1315 / 286 / 1 / 012003$

Maheshwari, S.P. (2014). Awareness of Green Marketing and Its Influence on Buying behaviour of Consumers: Special Reference to Madhya Pradesh, India. AIMA Journal of Management \& Research, 8(1).

Mantiaha, G.F (2016 (The Influence of Green Marketing on Consumer Buying Behaviour, J. EMBA, 4(2).

Marccaci, S. (2013). The Big Green Opportunity for America's Economy.

McEachern, M. Warnaby, G. Carrigan, M. \& Szmigin, I. (2010). Thinking Locally, Acting Locally? Conscious Consumers and Farmers Markets. Journal of Marketing Management, 26(5/6), 395-412. https://doi.org/10.1080/02672570903512494

Moisander, J. (2007). Motivational complexity of green consumerism. International Journal of Consumer Studies, 31(4), 404-409. https://doi.org/10.1111/j.1470-6431.2007.00586.x

N. Divyapriyadharshini, N. Devayani, S. Agalya, V. \& Gokulapriya, J. (2019). International Journal of Research and Innovation in Social Science, 3(10), 170 - 174

Nandini \& Deshpande, M. (2011). A Conceptual Framework on Green Marketing- A tool for Sustainable Development. International Journal of Sales and Marketing Management, 1(1), 1-16.

Nimse, P. Vijayan, A. Kumar, A \& Varadarajan, C. (2007). A Review of Green Product Databases." Environmental Progress, 26(2),131-137. https://doi.org/10.1002/ep.10210

Okada, E.M. and E.L. Mais. (2010). Framing the green alternative for environmentally conscious consumers, sustainability accounting. Management and Policy Journal, 1(2), 222-234. https://doi.org/10.1108/20408021011089257

Oliver, H., Volschenk, J. \& Smit, E. (2011). Residential consumers in the Cape Peninsula's willingness to pay for premium priced green electricity. Energy Policy, 39, 544-550. https://doi.org/10.1016/j.enpol.2010.10.012

Pagiaslis, A. \& Krontalis, A.K. (2014). Green Consumption behaviour antecedents: Environmental Concerns, Knowledge and Beliefs. Psychology and Marketing, 31(5), 335348. https://doi.org/10.1002/mar.20698

Park, S.J., Choi, S. and Kim, E.J. (2012). The relationships between socio-demographic variables and concerns about environmental sustainability. Journal of Corporate Social Responsibility and Environmental Management, 19(6), 343-354. https://doi.org/10.1002/csr.284

Rettie, Ruth, Burchell, Kevin and Riley, Debra (2012) Normalizing green behaviours: a new approach to sustainability marketing. Journal of Marketing Management, 28(3-4), 420-444. https://doi.org/10.1080/0267257X.2012.658840 
Saha, A (2017) A Framework for Studying Consumer Intention Towards Green Consumerism in India, Published by Tomas Bata University in Zlin in the Edition Doctoral Thesis

Saifur Rahman, A.S.M., Barua, A., Hoque, R \& Rifat Zahir, M.D (2017) Influence of Green Marketing on Consumer Behaviour: A Realistic Study on Bangladesh. Global Journal of Management and Business Research, 17(1).

Sakar, AN (2012) Green Branding and Eco Innovations for Evolving and Sustainable Green Marketing Strategy. Asia-Pacific Journal of Management Research and Innovation, 8(1), 39-58. https://doi.org/10.1177/2319510X1200800106

Samarasinghe, R (2012) The Influence of Cultural Values and Environmental Attitudes on Green Consumer Behaviour. International Journal of Behavioural Science, 7(1), 83-92.

Sandu, R (2014). Green: Marketing, Products and Consumers. Sea-Practical Application of Science, 2(3), 555-562.

Sawant, R. (2015). A Study on Awareness and Demand Pattens Amongst Consumers W.R.T Green products. Journal of Marketing and Technology (online), 5(1), 136-148.

Sharma, M \& Trivedi, P. (2016). Various Green Marketing Variables and Their Effects on Consumers" Buying Behaviour for Green Products, IJLTEMAS, 5(1), 2278 - 2540.

Sharma, P. (2015). Green Marketing - Exploratory Research on Consumers in Udaipur City. Journal of Applied Research, 5(1), 254-257.

Solomon, M. R., Bamossy, G., Askegaard, S \& Hogg, M.K. (2010). Consumer Behaviour: A European Perspective. 4th edition. New York: Prentice Hall

Su, L.J., Swanson, S.R., Hsu, M., Chen, X.H. How does perceived corporate social responsibility contribute to green consumer behaviour of Chinese tourists: A hotel context. Int. J. Contemp. Hosp. Manag., 29, 3157-3176. https://doi.org/10.1108/IJCHM-10-20150580

Suki, N. (2013). Green Awareness Effects on Consumers' Purchasing Decision: Some Insights from Malaysia. IJAPS, 9(2), 49-63.

Tanuj, G. Sourjo, M and Arpita, K. (2013). Social influence and green marketing: An exploratory study on Indian consumers. Journal of Customer Behaviour, 12(4), 361-381. https://doi.org/10.1362/147539213X13875568505903

Ting, Chung-Te, Hsieh, Chi-Ming, Chang, Hsiao-Ping, \& Chen Han-Shen. (2019). Environmental Consciousness and Green Customer Behaviour: The Moderating Roles of Incentive Mechanisms, MDPI, 1-16. https://doi.org/10.3390/su11030819

Wang, S. (2014). Consumer characteristics and social influence factors on green purchasing intentions. Journal of Marketing Intelligence and Planning, 32(7), 738-753. https://doi.org/10.1108/MIP-12-2012-0146 